\title{
Legal framework to ensure sufficient medical equipment, to train medical staff and to observe sanitary standards
}

\author{
By Theresa U. AKPOGHOME*
}

\section{A. Abstract}

Qualitative healthcare and universal coverage for health can only be achieved in a nation that has sufficient medical equipment, trained personnel and good sanitation. Without these, there can be no quality healthcare. Therefore, this paper examines the legal framework for the provision of sufficient equipment and training of medical staff and sanitation in Nigeria. The paper examines laws put in place by the government and observes that there are several laws in this regard but the problem bothers on implementation. The paper notes that all aspects of healthcare in Nigeria is tied to the annual budget and the federal government has not done so much in this regard as the health sector receives less than $5 \%$ vote from the budget as against $15 \%$ proposed in the AU Declaration. The paper also notes that health is not a justiciable right in Nigeria. It further notes that existing hospital equipment are dilapidated, sanitary condition is poor as there is no water and toilet facilities in most hospitals and this endangers the health of staff and patients. There is also brain drain in the sector as the personnel seek to earn a living in other climes with better welfare packages. The paper therefore recommends that the government should strive to provide the resources needed for equipment and training of medical staff by ensuring that $1 \%$ of its budget from the Consolidated Revenue Account is dedicated to the health sector. The paper concludes by noting that universal coverage for health in Nigeria is possible and if the right steps are taken, medical tourism will be a thing of the past. Most importantly, sanitation in the health sector should be added to the conversation.

Keywords: Healthcare, Legal Framework, Equipment, Medical, Training, Sanitation.

\section{Introduction}

Healthcare in any nation or country can only be described as qualitative when the hospitals are equipped with modern and functional equipment in addition to having trained personnel working in a clean and safe environment. Not only would these enhance the services to be provided by the hospitals but the patients whose immune systems have been weakened by diseases would stand a chance of surviving and not be faced with the threat of contracting other infections due to the unsanitary conditions of the hospitals. The maxim that a healthy nation is a wealthy nation cannot be overemphasized here. In the heat of the COVID - 19

* Akpoghome, Theresa U, PhD, LL.M, LL.B, BL., Professor, Department of Public Law, Faculty of Law, Benson Idahosa University, Benin City, Edo State, Nigeria. E-Mail: teremajor@gmail.com, takpoghome@biu.edu.ng. Ph:+2348065436545,+2348056317472. 
pandemic that engulfed the world, the issues bothering on sufficiency of medical equipment and trained medical personnel became bare as countries such as Nigeria was caught in the web of fighting the pandemic without the basic equipment such as the Personal Protective Equipment (PPE) and ventilators. So many medical personnel died ${ }^{1}$ because they were exposed to unsafe working environment while over 800 were infected. ${ }^{2}$

In spite of the challenge faced during the pandemic, it is observed that doctors and other health workers have raised issues regarding lack of medical equipment and brain drain in the medical field which has resulted to the death of so many patients that could have been saved and the situation encouraged medical tourism in Nigeria. It is in the light of the above that this paper examines the legal framework to ensure sufficient medical equipment, medical staff training and excellent sanitary conditions in the hospitals. To effectively discuss the issues raised, the paper is divided into five parts. Part I introduces the paper while part II discusses the legal framework put in place to ensure the provision of medical equipment. This section also examines the budgetary allocation to the hospitals as this is crucial in ensuring the provision and maintenance of new and existing equipment. Part III discusses the training of medical personnel to determine how prepared the workforce is in tackling/resolving health challenges in the country. Part IV examines the sanitary conditions in the hospitals as this is critical for both the personnel and the patients. Part V proffers solutions on how to remedy the defects observed in the study and concludes the paper.

\section{Legal Framework for Ensuring Sufficient Medical Equipment}

This section examines laws and policies existing in Nigeria that are geared towards ensuring effective and efficient healthcare delivery in the country. The healthcare system in Nigeria has had its fair share of challenges as noted earlier. Considering the position of Nigeria in Africa, the healthcare system is inadequately serviced and in a disadvantaged position. This can be seen in the areas of health facilities which includes the personnel, medical equipment and health centers which have been considered very inadequate both in the rural and urban areas but particularly the rural areas. The situation was aptly captured by the Secretary to the Government of the Federation, Boss Mustapha when he appeared before the National Assembly after he was appointed the Chairman of the Presidential Taskforce on COVID-19. He stated:

1 Mwai, P. and Cules, C., "Corona Virus: How vulnerable are Health workers in Nigeria", http://www .bbc.com/news.world-a/. See also Corona Virus Kills Brilliant Doctors in Nigeria”, http://www.bbc. $\mathrm{com} /$. (Last accessed 29 September 2020).

2 Obaseki, D.E. "Nigeria: 800 Health Workers Infected with Covid - 19, http://www.ac.com.tr/africa/ nigeria - 800-health-workers-infected-with-covid-19/, See also https://www.panAfrican-med-journa 1.com. (Last accessed 29 September 2020). Obaseki, D. E., "Staff Risks Stratification in Preparation for Covid - 19 in a Tertiary Healthcare Facility in Nigeria", Pan African Medical Journal, Vol. 35, No. 2, (2020), https://wwwpanafrican-med-journal.com/content/series/3/2/124/full/ (Last accessed 3 October 2020). 
I can tell you for sure, I never knew that our entire healthcare infrastructure was in the state in which it is until I was appointed to do this work. If developed countries of the world are stretched despite their good capacity, then Nigeria needs to improve its own. My prayer is that Nigeria's situation does not escalate to that extent because the country lacks what is required to handle the situation. ${ }^{3}$

It then raises the question as to what laws have been put in place to check and ameliorate these deficiencies. We shall be looking at the grund norm of the country i.e. the Constitution of the Federal Republic of Nigeria 1999 as amended, the African Charter on Human and Peoples Right (Ratification and Enforcement) Act, the National Health Act 2014, the Appropriation Act of 2020 and the Health Policy 2017. Aside the provisions in the above legislations, it is important to note that the right to health is also contained in the Universal Declaration of Human Rights and the International Covenant for Economic Social and Cultural Rights.

\section{The Constitution of the Federal Republic of Nigeria}

The Constitution of the Federal Republic of Nigeria ${ }^{4}$ in chapter II under social objective policy made provisions for health facilities and it reads:

The state shall direct its policy towards ensuring that, there are adequate medical and health facilities for all persons. ${ }^{5}$

The above provision appears properly couched in good intentions but in reality, the government has failed to direct its policy in this regard. This provision of the Constitutions falls under the "Directive Principles of State Policy which is not justiciable and all the items fall under the socio-economic rights which the government is expected to actualize based on the availability of funds or resources as progressive attainment is the word used in the International Covenant for Economic and Social Rights. ${ }^{6}$

The provision of adequate health and medical facilities belong to the class of rights to be achieved progressively based on availability of resources and this clearly explains the

3 Igomu, T., 'I Didn't Know that Nigeria's Health Sector was this Bad- Boss Mustapha', April 10 2020, https://www.healthwise.punchng.com. (Last accessed 28 September 2020). This is what health tourism has caused the nation. Our political class is detached from the realities on ground. One wonders what this class of people would be able to achieve when they do not know the gravity of the situation that Nigerians face on a daily basis. He promised that funds donated would be used to purchase basic equipment but Nigerians never saw any improvement.

4 Hereafter CFRN 1999 as amended 2011.

5 Section 17 (3) (d) CFRN 1999 as amended 2011.

6 International Covenant for Economic and Social Rights (ICESCR). See also Akpoghome, T. U. and Nwano, T. C., 'State Funding of Public Institutions in Nigeria: Control Mechanisms and Legal Challenges', KAS African Law Study Library, Vol. 4, No. 6, (2019), Pp. 541-562 at 557. The authors reiterated that the non justiciability of the health provision in the Nigerian Constitution is a huge set back to ensuring that the health sector gets the attention it deserves. 
level of rot and decay or obsoleteness of medical facilities in our hospitals. This provision gives the government at all levels an escape route not to commit to the realization of this objective. The Primary Health Care (PHC) centers are burdened by lack of facilities compelling people to visit secondary health care institutions thereby making the secondary facilities overcrowded and stretching whatever equipment that exists in those institutions. The tertiary facilities run by the federal government is not exonerated from this menace of dilapidated and obsolete equipment. Due to the fact that this provision is contained under chapter II of the Constitution it is non justiciable. ${ }^{7}$ This makes it difficult for citizens to institute actions against the government in the face of insufficiency of medical and health facilities in pursuance of their right to qualitative healthcare.

\section{African Charter on Human and Peoples Rights}

The African Charter on Human and Peoples Rights (ACHPR),${ }^{8}$ is another piece of legislation that makes provision for health care. It's a regional instrument but has been ratified and domesticated by Nigeria. The ACHPR did not specifically mention health facilities and equipment but it provides that:

Every individual shall have the right to enjoy the best attainable state of physical and mental health, ${ }^{9}$ and that States Parties to the present Charter shall take the necessary measures ${ }^{10}$ to protect the health of their people and to ensure that they receive medical attention when they are sick. ${ }^{11}$

Looking at the above provision critically, it becomes obvious that the provision of medical and health facilities can be read into it as no citizen can enjoy the 'best attainable state of physical and mental health in the absence of medical facilities that are up-to-date and sufficient to take care of the different health issues to be presented by the citizens. Again, the Charter encourages States Parties to take all 'necessary measure' to protect, the health of the people and also to ensure that these citizens receive medical attention. By implication, the Charter irrefutably presumes that there should be adequate health and medical equipment, personnel and a clean and conducive environment that will lead to the attainment of good health for the citizens.

7 Section 6 (6) (c) of the CFRN 1999. In section 6(1) the constitution provides that the judicial powers of the federation shall be vested in the courts.... in section 6(6), it went further to state that the judicial powers vested in accordance with the foregoing provision of this section - (c) shall not, except as otherwise provided by this constitution, extend to any issue or question as to whether any act or omission by any authority or person or as to whether any law or any judicial decisions is in conformity with the fundamental objectives and directives principle of state policy set out in chapter II of this constitution.

8 Ratification and Enforcement Act, Cap A9 Laws of Federation of Nigeria (2004).

9 Article 16 (1) ACHPR.

10 Emphasis mine.

11 Article 16(2) ACHPR. 
Despite this laudable provision, the state of medical and health facilities are not encouraging in Nigeria. Just like the Constitution, this piece of legislation cannot be judicially enforced in our courts. The provision of Article 16 of the ACHPR is justiciable in ECOWAS Court but runs contrary to the provision of the grund norm ${ }^{12}$ thereby making it unenforceable by the courts in Nigeria.

\section{The National Health Act 2014}

The National Health Act establishes the National Health System (NHS) which shall define and provide a framework for standards and regulation of health services. ${ }^{13}$ The National healthcare approach is based on the three tier system noted earlier involving the federal, state and local governments. ${ }^{14}$ The three tiers would include the Primary Health Care, Secondary and Tertiary Care systems. It is the duty of the Federal Ministry of Health (FMH) to develop strategies, policies, guidelines, plans and programmes that will give a direction to the entire National Health Care delivery Systems. ${ }^{15}$ The Primary Health Care (PHC) is to be the responsibility of the local government, the secondary institutions of healthcare are run by the state government and the federal government is responsible for the tertiary care. ${ }^{16}$

The National Health Act did not specifically mention the provision of sufficient medical equipment but provides for the basic health care provision fund. ${ }^{17}$ This fund shall be financed by the federal government by the provision of an annual grant of not less than one percent $(1 \%)$ of its Consolidated Revenue Fund, Grants by international donor partners, and funds from any other sources. ${ }^{18}$

One can glean from the above that the surest means of providing the fund is from the annual grant of $1 \%$ from the consolidated revenue fund of the federal government. This one percent should be provided for in the annual budget.

12 The Constitution in section 1(3) provides that: if any other law is inconsistent with the provision of this constitution this constitution shall prevail, and that other law shall to the extent of the inconsistency be void.

13 Section 1 National Health Act - Establishment of the National Health System.

14 Section 1 (2) National Health Act 2014.

15 Section 2 National Health Act 2014.

16 Section 1 (2) (a) (b) National Health Act 2014. See also Medic West Africa, "2019 Health Care Market Insights: Nigeria", http://www.medicwestafrica.com/content/dam/informa/medic-west-afei ca/englis/2019/healthcareinsight.pdf/ (Last accessed 27 September 2020).

17 Section 11 (1) National Health Act 2014.

18 Section 11 (2) (a) - (c) National Health Act 2014. 
On the distribution of this $1 \%$ fund the Act provides that:

$50 \%$ of the fund shall be used to provide basic minimum package of health services to citizen, in eligible primary and secondary healthcare facilities through the National Health Insurance Scheme (NHIS). ${ }^{19}$

What constitutes the basic minimum package is not defined and the NHIS coverage is very poor. Less than $5 \%$ of Nigerian citizens enjoy the coverage in a country with over 200 million citizen in over a decade of its implementation. ${ }^{20}$ The Act further provides that $20 \%$ of the fund shall be used to provide essential drugs, vaccines and consumable for eligible primary healthcare facilities ${ }^{21}$ while $15 \%$ of this same fund shall be used for the provision and maintenance of facilities, equipment and transport for the eligible primary health care facilities. $^{22}$

Obviously, the fund is basically made to serve the needs of the primary healthcare facilities. If this is so, why then are the PHCs in Nigeria not functional. In these PHC's there dearth of facilities and staff and this has led to over burdening of the secondary and tertiary health care facilities. It is also a possibility that the situations in the PHC's have remained due to inability of the local governments or state governments to provide counterpart funding as required by the Act, ${ }^{23}$ thereby losing out on the portion to be provided by the federal government. A more serious argument is the fact that the federal government over the years have not set out this $1 \%$ of the budget to meet these need. Some of the issues relating to the fund will be examined under the heading - budgetary allocation for the Health Sector.

\section{National Health Policy 2017}

While the National Health Act of 2014 provides the legal framework for the development, regulation and management of a national health system by setting standards for provision of services, the National Health Policy that became effective in February 2017 provides the

19 Aregbeshola, B.S and Khan, SM 'Predictors of Enrolment in the National Health Insurance Scheme among Women of Reproductive Age in Nigeria', International Journal of Health Policy and Management, Vol. 7, No (1), (2018), Pp. 1015 - 1023, https:/www.nobi.nlm.nih.gov/articles/ (Last accessed 29 September 2020).

20 The NHIS implementation began in the year 2005.

21 Section 11(3) (b) National Health Act 2014.

22 Section 11(3) (c) National Health Act 2014.

23 Section 11 (5) (a) - (b) National Health Act 2014. Section 11 (6) (a) - (c) appears to have put the nail in the coffin when it provides that the National Primary Healthcare Development Agency shall not disburse money to any local government Health Authority if it is not satisfied that the money earlier disbursed was applied in accordance with the provision of the Act; if state or local government has failed to contribute its counterpart funding and if the state or local government fails to implement the national health policy, norms, standards and guidelines prescribed by the National Council on Health. 
platform for a synergy with the National Health Act 2014 geared towards actualizing the United Nations Sustainable Development Goal (SDG) on Universal Health coverage. ${ }^{24}$ The National Health Policy (NHP) provides a framework or platform for bringing together resources for health development with particular attention on primary healthcare systems and tries to increase the efficiency and affordability of health care service delivery. It lists its agenda in 10 areas of focus that would enable it to achieve the stated objectives and these areas include: governance, financing, medicines and vaccines, infrastructure, data systems, research and development, Public - Private Partnership (PPP) and community participation. ${ }^{25}$ Despite the fact that the Federal Ministry of Health is in charge of the policy, ${ }^{26}$ Nigeria's healthcare system is yet to provide the level of service required to meet the needs of the citizens.

Looking at the NHP on issue of infrastructure/equipment it can be seen that there are about 43, 173 health facilities across the 36 states and the federal capital territory (FCT); 30, $098(88 \%)$ are primary Health care facilities, $3992(12 \%)$ are secondary facilities, while $83(1 \%)$ are tertiary facilities. ${ }^{27}$ Over $66 \%$ of these facilities are owned by government. ${ }^{28}$ This is as at 2011, nine years ago, these numbers would have increased in 2020. There are about 11, 323 healthcare facilities privately owned in Nigeria. ${ }^{29}$ The National Health Policy notes that physical infrastructures such as buildings, pipe borne water, good access roads, electricity and transportations are deficient in most locations. ${ }^{30}$ It also noted that technological equipment for hospital use such as surgical equipment, computers, power generating plants, and consumables are inadequate. ${ }^{31}$ It also noted that there is poor facility management and maintenance culture and lack of standardization for health infrastructures. $^{32}$

As noted earlier in the paper the NHA 2014 provides that $15 \%$ of the Basic Healthcare Provision fund should be made available for the financing obligations for the provisions and maintenance of health infrastructure. ${ }^{33}$ In the face of obvious lack of equipment in the

24 Medic West Africa (n16) p3.

25 Federal Ministry of Health National Health Policy 2017 (Abuja: 2017) pp ii, item 2.5, pp 11 - 25.

26 The federal government health policy aims to improve the availability, accessibility, affordability and quality of health services by increasing access to primary healthcare services, expanding health coverage and improving the quality of the services provided. The ministry of health as noted is leading the policy initiatives that includes the revitalization of the primary healthcare system, the rollout of universal health coverage, strengthening delivery, develop mega health services and optimizing the health to population ratio in Nigeria.

27 National Health Facility List, 2011, Federal Ministry of Health.

28 Ibid.

29 Ibid.

30 Ibid.

31 Ibid.

32 Ibid.

33 Section 11 (3) (c) NHA 2014. 
healthcare sector, the National Health Policy goal to have an adequate and a well distributed network of healthcare infrastructure that meets the quality and safety standing ${ }^{34}$ may not be achieved in the nearest future.

To achieve the above goal, the NHP set out three main objectives and they are:

(a) To improve availability and distribution of functional health facilities across the country to ensure equitable access to health services, especially in underserved area;

(b) To ensure compliance with quality standards and requirements for facilities and biomedical equipment

(c). To ensure effective maintenance of health equipment and infrastructure at all levels.

Some of the policy orientations and initiatives of the National Health Policy for the achievement of infrastructural development includes but not limited to:

(i) Ensure the efficient utilization of the $15 \%$ allocation from the Basic Healthcare provision fund for the maintenance of health structure, equipment and transport for eligible primary care facilities in line with the NHA $2014^{35}$

(ii) Promote adherence to all quality requirements and standards for equipment and safety for all the various categories of health facilities;

(iii) Strengthen the implementation of the issuance of and compliance with the certificate of standards in line with the National Health Act $2014^{36}$

(iv). Ensure the classification of health establishments according to the National health Act 2014 to guarantee efficiency and equitable access to health services ${ }^{37}$...

The listed initiatives above are quite laudable and would greatly enhance the provision of sufficient equipment and infrastructure if the $15 \%$ from the fund is made available to the federal ministry of health. In other words, infrastructural development is tied to the availability of funds through the annual budget.

5. Budgetary Allocation to the Health Sector in 2020 Appropriation Act

The Ministry of Health received a meager budget of N427.30 billion which represents $4.14 \%$ of the 2020 budget. $^{38}$ This according to experts is dangerous for the actualization of

34 National Heath Policy Goal on Infrastructure.

35 Section 11 (33) (c) NHA 2014.

36 Section 13 (1) (a) - (d) NHA 2014. It provides that: without being in possession of a certificate of standards, a person, entity, government or organization shall not establish, construct, modify or acquire a health establishment, health agency or health technology; increase the number of beds in or acquire prescribed health technology at a health establishment or health agency; provide prescribed health services, or continue to operate a health establishment, health agency or health technology after the expiration of 24 months from the date this Act took effect.

37 Section 12 NHA 2014.

38 Olufemi Joshua, 'Nigeria budgets N2,000 for the Healthcare of each citizen in 2020 https://ww.pre muimtimesng.com/health/health-feature/361373-nigeria-budgets-n2000-for -the-healthcare-of-eac h-citizen-in-202.html/ (accessed 27 September 2020). The proposed budget for 2021 just presented 
the universal health coverage. If you break this figure down, it simply means that every Nigerian is entitled to N2, 000 (two thousand) naira worth of Medicare in $2020 .{ }^{39}$ This is a far cry from the WHO proposal of 2017 where the organization says that for Nigeria to be seen to prioritize healthcare, it must at least spend a minimum of N6, 908 per Nigerian in a year. ${ }^{40} 2017$ was a period that Nigeria did not experience a pandemic. The WHO was convinced that Nigeria is not giving the health sector the priority and attention that it deserves.

Nigeria's health indices as provided by the World Health Organization reveals how terrible the situation is. Nigeria still has a high rate of maternal death. ${ }^{41}$ All the pregnant women do not have access to antenatal care and few deliver their babies having skilled health staff attending to them. ${ }^{42}$ Not all the children are immunized thereby exposing them to diseases such as polio and meningitis. ${ }^{43}$ Children still die in Nigeria from malaria attacks. ${ }^{44}$ The 2020 budget for the health sector shows that there is an increase when compared with the 2019 budget for health. In 2019 government budgeted N424.03 billion and in 2020 it increased to N427.30 billion showing a 0.77 percent increase. ${ }^{45}$ In 2019 recurrent expenditure stood at N315.72 billion and in 2020, it is N336.32 billion. ${ }^{46}$ Capital expenditure in 2019 was N57.08 billion and in 2020 it dropped to N46.47 billion. ${ }^{47}$ The basic healthcare fund in 2019 was N51.22 billion and in 2020, it dropped to N44.50 billion. ${ }^{48}$ This obviously does not reflect the $1 \%$ as stipulated in the National Health Act of $2014 .{ }^{49}$

Going by the 2020 appropriation, the consolidated revenue fund is N10.33 trillion. This means that $1 \%$ allocation to the basic healthcare fund should be N103.3 billion and not

to the National Assembly by President Buhari shows that the budget for the health sector has reduced to N132 billion.

39 Ibid. See also Akpoghome and Nwano (n6) p 552-553 where the authors observed that poor funding has been identified over the years as the major reason for the rot and decay in the health and education sectors.

40 Umeha, Chioma, 'Nigeria's grossly Inadequate 2017 Health Budget https://www.thisdaylive.com/i ndex.php/2017/02/09/nigerias-grossly-inadequate-2017-health.budget/ (Last accessed 27 September 2020).

41 It was reported that between 2005 and 2015, over 600,000 maternal deaths happened and not less than 200,000 maternal near miss cases occurred. In all, maternal mortality rate is approximately 800 per 1000 live birth and 58,000 maternal death in 2015 alone.

42 Olufemi (n 38).

$43 \mathrm{Ibid}$. In 2017, there were 1407 cases and 211 resulted in death.

44 Nigeria Malaria factsheet estimates that there are over 300,000 malaria deaths per year with 100 million cases. This is outside the fact that malaria contributes to an 11 percent mortality rate in the country.

45 Olufemi (n38).

46 The increase in the recurrent expenditure is 6.53 percent.

47 This is reduction by 18.58 percent.

48 The basic Health care fund dropped by 13.12 percent.

49 Section 11 (3) (a) - (e) National Health Act 2014. 
N44.50 billion. The budget is a far cry from the provision of the Act. It is observed that although the consolidated revenue fund continues to increase and is the basis for the allocation to the basic health care fund, this increase has not reflected in the money set aside for the BHCF. ${ }^{50}$ With 4.14 percent allocation to the health sector, one wonders how Nigeria wishes to achieve universal health coverage for the citizens. Nigeria in 2001 signed the Abuja Declaration alongside other countries of the African Union and the Declaration recommended that African nations should allocate 15 percent of their annual budget for healthcare if the continent would be at par with other nations of the World. ${ }^{51}$ The World Health Organization standard is 13 percent. ${ }^{52}$ Fortunately some African countries are already taking steps towards the actualization of better healthcare for their citizens. ${ }^{53}$

There is very meager funds to use in purchase of health facilities and equipment as provided under the Health Act. The Federal Ministry of Health cannot do much without funds and this practically stalls the National Health Policy. The COVID - 19 pandemic exposed the dearth of infrastructure and equipment in Nigerian Hospitals. There were no Personal Protective Equipment (PPE) for health workers, test kits were not readily available, test centers/laboratories were not in existence and ventilators were donated to Nigeria by foreign countries such as the United States of America and China. Doctors' allowances were not paid and these led to strikes by the health workers. ${ }^{54}$

\section{Training of Medical Personnel}

The training of medical personnel is regulated by the Medical and Dental Practitioners Act, the Nursing and Midwifery Legislation, the National Health Act and the Code of Medical Ethics in Nigeria and the National Health Policy 2017. These laws have in one way or the other made provision for the training and distribution of health officials. It also covers the issue of strike and the welfare of medical practitioners in the national healthcare system.

50 The year 2020 has witnessed the lowest allocation to the BHCF. In 2018 BHCF received N55.15 billion, 2019 it got N51.22 billion and in 2020 it was allocated N44.50 billion. This is an indication that the government is paying lip service to healthcare.

51 Umeha (n40) p2.

52 Ibid.

53 Rwanda was reported to have devoted 18 percent of its 2016 budget to healthcare, Botswana 17.8 percent, Malawi 17.1 percent, Zambia 16.4 percent and Burkina Faso 15.8 percent while that of Nigeria for the year under review was 4.17 percent.

54 Aworinde, T., 'COVID - 19 Exposes Nigeria's Wobbling Healthcare System' https://wwwhealthwi se.punching.com/covid-19-exposes-nigeria-nobbling-healthcaresystem/ (Last accessed 27 September 2020). See also Adie Vanessa Offiong. 'Nigeria: A Pandemic and a Weak Health System, https://www.gga.org/nigeria-a-pandemic-and-a-weak-health-system/ (Last accessed 27 September, 2020). See also 5 Challenges Facing Healthcare Workers in Nigeria as they Tackle COVID-19, https://www.globalcitizen.org/en/content/challenges-facing-health-care-workers-an-Ni geri-covid/ (Last accessed 27 September 2020). 
We shall examine some of the provisions of these laws as it would help us determine the adequacy of training received by medical personnel in Nigeria.

a. The medical and Dental Practitioners Act

The Medical and Dental Practitioners Act ${ }^{55}$ establishes the Medical and Dental Council of Nigeria $^{56}$ that has been with saddled with the responsibility of training medical personnel. The Act provides inter alia that the Council shall have the responsibility for:

- Determining the standard of knowledge and skill to be attained by persons seeking to become members of the medical or dental profession and receiving those standards from time to time as circumstances may permit, ${ }^{57}$

- Securing in accordance with the provisions of this Act, the establishment and maintenance of registers of persons entitled to practice as members of the medical or dental profession and the publication from time to time of lists of those persons, ${ }^{58}$

- Reviewing and preparing from time to time, a statement as to the code of conduct which the council considers desirable for the practice of the professions in Nigeria, ${ }^{59}$

- Supervising and controlling the practice of homeopathy and other forms of alternative medicine, ${ }^{60}$

- Making regulations for the operation of clinical laboratory practical in the field of pathology which includes Histopathology, forensic pathology, Autopsy and cytology, clinical cytogenetic, Hematology, Medical Micro biology and Medical Parasitology, Chemical Pathology, Clinical Chemistry, Immunology and medical Virology; ${ }^{61}$ and

- Performing other functions conferred on the council by this Act.

From the provision of the Act it can be seen that the Council has about four mandates and they are: the regulation of training in Medicine, Dentistry and alternative medicines in Nigeria; regulation of Medical, Dental and alternative Medicine practice in Nigeria; Determination of the knowledge and skill of these professionals; Regulation and control of Laboratory medicine in Nigeria. ${ }^{62}$

55 CAP M8, Laws of the Federation of Nigeria, 2004.

56 Hereinafter the 'Council'. The Council is a body corporate with perpetual succession and a common seal. It can sue and be sued in its corporate name.

57 Section 1 (2) (a) Medical and Dental Practitioners Act, Cap M8, LFN 2004 hereinafter MDPAN 2004.

58 Section 1 (2) (b) MDPAN 2004.

59 Section 1(2) (c) MDPAN 2004.

60 Section 1 (2) (d) MDPAN 2004.

61 Section 1 (2) (e) MDPAN 2004.

62 The mission statement of the Council is to regulate the practice of medicine, Dentistry and Alternative medicine in the most efficient manner that safeguards best healthcare delivery for Nigerians. 
The regulation of training in medicine, dentistry and determination of the knowledge and skill of these professionals imply that the Council plays very prominent role in the accreditations of medical schools ${ }^{63}$ and also involved in the retraining of the professionals by conducting professional examinations for the practitioners at different stages of their practice in order to determine their knowledge and skills. ${ }^{64}$ These professional examinations determine the levels to which a practitioner may rise to in his/her chosen field of medical practice. Practitioners who hold the required qualifications after attending a course of training approved by the Council ${ }^{65}$ and at an institution so approved ${ }^{66}$ shall be entitled to be fully registered as medical practitioners or a dental surgeons in Nigeria. ${ }^{67}$

The Council in the exercise of its powers shall not approve a qualification granted by an institution except that qualification bears bachelor of medicine and surgery or bachelor of dental surgery. ${ }^{68}$ The Council can also institute or conduct an assessment or examination for holders of foreign medical or dental qualifications that are recognized by the government of the issuing country. ${ }^{69}$ The Council from time to time supervises the instructions and examinations leading to approved qualifications. ${ }^{70}$ This is to enable it determine the sufficiency of the instructions given to persons attending the approved courses of training at institutions and the sufficiency of the examination attended by such persons. ${ }^{71}$

Once a person qualifies after attending the approved course of training and examination a certificate of experience shall be issued to him free of charge. ${ }^{72}$ A person so issued with a certificate of experience is expected to pay his practicing fee without which he/she would not be allowed to practice. ${ }^{73}$ Medical practitioners or dental surgeons are exempted from payment of practice fee in the year of their National Youth Service Corps. ${ }^{74}$ The Act also

63 Section 9(b) MDPAN 2004.

64 Section 9(1) (a) -(c) MAPAN 2004.

65 Section 8(1) (a) (c) MDPAN 2004.

66 Section 8 (1) (b) MDPAN 2004.

67 Section 8 (1) MDPAN 2004. See section 6 Code of Medical Ethics in Nigeria.

68 Section 9(2) (a) (b) MDPAN 2004.

69 Section 9(3) MDPAN 2004.

70 Section 10 (a) (b) MDPAN 2004. The supervision of instruction and examination is done by the Council either by appointing its own members or other approved persons to visit approved institutions to attend such examination at least once every three years. See section 10(1) (b) MDPAN 2004.

71 Section 10 (2) (a) - (c) MDPCA 2004.

72 Section 11 (1). This certificate of experience is issued subject satisfying all other conditions listed under subsection (2) (a) - (c) of this section.

73 Section 14 (1) (a) - (d) MDPCAN 2004.

74 Section 14 (2) MDPAN 2004. 
makes provision for disciplinary and investigative measures ${ }^{75}$ and penalties for professional misconduct. ${ }^{76}$

\section{b. The National Health Act}

The National Health Act provides that $10 \%$ of the Basic Healthcare Provision Fund shall be used for the development of human resources for the primary healthcare. ${ }^{77}$ How this will be achieved is not very clear as the government is still unable to dedicate $1 \%$ of its annual budget to the fund. The Act also provides for the rights of healthcare personnel. ${ }^{78}$ Furthermore the Act charges the National Council on Health to develop policy and guidelines for, and monitor the provision, distribution, development, management and utilization of human resources within the national health system. ${ }^{79}$

The policy and guidelines to be developed should inter alia ensure the adequate distribution of human resources; provision of appropriately trained staff at all levels of the national health system, to meet the populations health needs and for effective and efficient utilization, functioning, management and support of human resources within the health system. ${ }^{80}$ The Act mandates the Minister of Health and the National Council to determine guidelines that will enable the state ministries and local government to implement programmes for the appropriate distribution of healthcare providers and health workers. ${ }^{81}$

In addition to the guideline, the Minister is also to makes regulations with regard to human resources management and this provision is quite detailed. ${ }^{82}$ The Minister is to ensure the provision of adequate resources for education and training of healthcare personnel; ensure that this education and training meets the requirements of the health system; including re-certification programmes for continuing professional development; create new categories of personnel to be educated or trained; identify areas of shortage of key skills, expertise and competence and to prescribe strategies that would not conflict with any legislation for the education and training in order to make up for the shortfall in respect of any skill, expertise and competence; prescribe strategies for recruitment and retention of healthcare workers from within and outside Nigeria. ${ }^{83}$

These provisions are quite laudable and if implemented, the Nigeria health sector would be one of the best in the world. The Minister in response to this call has developed the Na-

75 Section 15 MDPAN 2004.

76 Section 16 MDPAN 2004.

77 Section 11 (3) (d) National Health Act 2014.

78 Section 21 National Health Act 2014.

79 Section 41 (1) National Health Act 2014.

80 Section 41 (2) (a) - (c) National Health Act 2014.

81 Section 42 National Health Act, 2014.

82 Section 43 National Health Act 2014.

83 Section 43 (a) - (e) National Health Act 2014. 
tional Health Policy to drive these goals and initiatives but it must be noted that without adequate funding the Federal Ministry of Health will not be in a position to achieve these directives. The lack of fund from the consolidated revenue of the federation to the Health sector has given rise to myriads of problems and challenges. Infrastructures are lacking ${ }^{84}$ and the existing ones are overstretched and not maintained. ${ }^{85}$ There is brain drain in the health sector and this has encouraged medical tourism by those who can afford it. Most Nigerians can only afford quality healthcare via out-of-packet expenses. ${ }^{86}$ To provide qualitative healthcare that will answer to the Universal Coverage on Health the Nigerian government at all levels need to do more.

\section{c. The National Health Policy 2017}

On the subject of human resources for health, the situation analysis from the Federal Ministry of Health noted that as at 2012, Nigeria had 27 accredited medical schools most of which are in the southern part of the country ${ }^{87}$ and every year about 2,300 students graduate from these schools. ${ }^{88}$ Today there are 25 colleges of medicine with full accreditation and 3 with partial accreditation and approximately 306 health training institutions. ${ }^{89} 236$ of these institutions are dedicated to the training of Nurses and Midwives. ${ }^{90}$ Some have full accreditation while some others have provisional accreditation status and some have theirs withdrawn. The highest quota is 100 for a school and the least was 20 students. ${ }^{91}$ The quota places a benchmark on the number of graduates that would be admitted into the nursing and midwifery profession. The quota is not limited to Schools of Nursing and Midwifery but to

84 'The Six Biggest Issues with Healthcare Services in Nigeria and how FM can Help', https://www.a mfacilities.com/wp-content/uploads/2016/10/HEALTHCARE-blog-banner.jpg/. (Last accessed 1 October 2020). This article notes that lack of modern equipment and the obsoleteness of the existing ones is the biggest issue with the Nigerian health care system. This can give rise to medical errors that would result in harm or death to the patients which could have been avoided. This also encourages medical tourism.

85 It is observed that $90 \%$ of the lifecycle of any asset is dependent on its maintenance. This is quite instructive because when we look around, we see that the public health centers/institutions are mere shell buildings and the private institutions are also succumbing to the wear and tear. The Medical Equipment Maintenance Policy of 2005 only exists on the shelves of medical libraries.

86 The private sector is responsible for about two-third of health care spending and $95 \%$ is paid out of pocket due to the fact that less than $5 \%$ of the population enjoys the NHIS coverage.

87 Nwariaku, F., 'Performance of Medical Graduates within and Outside', Nigeria Medical Journal, Vol. 51, No 2, (2010), p 1, https://www.ajol/info/index.php/nmj/articles/ (Last accessed 2 October 2020).

88 Situation Analysis of the Federal Ministry of Health, $\mathrm{p} 18$.

$89 \mathrm{Ibid}$. p. 19. These include but not limited to the Medical and Dental Council, the Pharmacists Council of Nigeria, the Nursing and Midwifery Council, Community Health Practitioners Board, Medical Lab Science Council.

90 Federal Ministry of Health (n88).

91 Ibid. 
all medical schools. The quota helps to place a check on the various institutions and helps in the attainment of excellence in the profession.

A school loses accreditation due to lack of appropriate infrastructure and personnel. This also have a negative impact on the ability of Nigeria to produce adequate number of health workers in the long run. Nwariaku $u^{92}$ and the Federal Ministry of Health ${ }^{93}$ noted that Nigeria has one of the largest stock of human resources in the health sector. These figures appear impressive but there is a dearth of manpower in the various categories of the health sector. There is also the challenge posed by the distribution of health workers in the rural and urban areas. The Federal Ministry of Health notes that there are 14 professional regulatory bodies saddled with the responsibility of training, practice and the maintenance of standards. ${ }^{94}$ These professional regulatory bodies are constrained due to weak structures and poor institutional capacities to carry out their statutory functions which includes the effective monitoring of health professionals and the accreditation of institutions within their areas of competence. ${ }^{95}$ The goal of the National Health Policy in this area is to:

Strengthen the institutional framework for human resources planning, production, recruitment, distribution, management and practices in the health sector; ${ }^{96}$ Ensure clarity in the roles and responsibilities of actors at all levels on human resources for health planning, production and management. ${ }^{97}$

To achieve the above goal, the Federal Ministry of Health has developed policy orientation and initiatives which includes to strengthen the utilization of evidence-based planning and projections of the human resources for health, including medium and long term planning for health; improve the production of human resources for health including the training of specialized health workers cadres through the completion and implementation of a national Human Resources for Health (HRH) policy and strategic plan and their adaptation by the state government; foster effective collaboration with the regulatory bodies in both the education and health sectors; promote reforms on the performance management systems for all cadres of health workers; institute measures that promote equitable distribution and retention of human resources for health at all levels of the health system, including improving the conditions of service especially in rural settings, strengthen the capacity of professional regulatory bodies to ensure compliance with the ethical standards and norms for health care delivery; strengthen the HRH information system; develop and implement mechanisms to

92 Nwariaku (n87).

93 Situation Analysis of the Federal Ministry of Health, p 18.

94 Ibid, p 19. These include but not limited to the Medical and Dental Council, the Pharmacists Council of Nigeria, the Nursing and Midwifery Council, Community Health Practitioners Board, Medical Lab Science Council.

95 Ibid.

96 National Health Policy 2017, Objective of the Health Policy for Human Resources for Health.

97 Ibid. 
minimize rivalries between professional health workers ${ }^{98}$ and also minimize industrial unrest (strikes); ${ }^{99}$ develop and implement measures to address the post graduate specialty training challenges in health care; develop and implement measures to reduce the existing "conflict of interest" problem of medical/health workers; ${ }^{100}$ and ensure the effective and efficient use of $10 \%$ of the basic health care provision fund for the development of human resources for primary healthcare.

\section{d. Nursing and Midwifery Council of Nigeria}

The Nursing and Midwifery Council of Nigeria ${ }^{101}$ is a category B parastatals of the Federal Ministry of Health. It is a body corporate with perpetual succession and a common seal. It is the only legal, administrative, corporate and statutory body charged with the performance of specific functions on behalf of the federal government. These functions are necessary in order to ensure the delivery of safe and effective nursing and midwifery care to the public through quality education and best practices. ${ }^{102}$

98 The rivalry among the medical/health practitioner in the country is unprecedented. If the National Association of Resident Doctors embark on strike, once their demands are met, the Joint Health Employee Staff Union (JOHESU) would proceed on strike too demanding to be treated equally as doctors, then the Nurses. There seems to be no end to this rivalry. Recently in September 2020, JOHESU continued with their strike which has lasted for three weeks shutting down health facilities. In an interview JOHESU claimed that the strike would not be called off as the Ministry of Health is favoring doctors over other health professionals. See Adepoju, P., 'Nigeria's nationwide Health Workers Strike Bites Harder at UCH Ibadan' https://www.healthnews.ng/nigeria-nationwi de-health-workers-strike-Ibadan,https://www.healthnews.ng/Nigeria-nationwide-health-workersstike-bites-harder-at-uch-ibadan/ (Last accessed 27 September 2020).

99 A look at section 45(1) and (2) gives an impression that the government would do all that is within their powers to avert industrial disputes and strikes. Sub section (3) provides that where there is a disruption of health services in any sector of the national health system, the minister shall apply all reasonable measures to ensure a return to normalcy of any such disruption within 14 days of the exercise thereof. In 2016, 16,000 resident doctors all over Nigeria proceeded on strike during the fight against Ebola, in 2020, resident doctors all over Nigeria proceeded on strike to press home their demands for a better welfare package and the provision of basic medical facilities to help them protect themselves in the line of duty as COVID -19 ravaged the country. They demanded for insurance covers. JOHESU also went on strike for the same reasons in September, 2020. The insincerity of government in tackling the problems in the health sector becomes unbearable whenever there is an emergency health need in the nation. They try to meet with most of the demands from this sector to pacify the workers and as soon as the protests are over, the government would renege on its promises until another emergency in the health sector occurs and the cycle of agitations would resume.

100 Due to poor welfare packages for doctors most of them prefer to run their own clinics even when they are employed by the government using the time they should dedicate to their paid employment to run their personal and private clinics.

101 Nursing and Midwifery (Registration etc.) Act Cap N143, Laws of Federation of Nigeria, 2004, https://www.nncn.gov.ng/ (Last accessed 3 October 2020).

102 Ibid. 


\section{e. The Pharmacist Council of Nigeria}

Pharmacy practice is regulated in Nigeria by the Pharmacist Council of Nigeria (PCN). It is a federal government parastatals established in $1992 .{ }^{103}$ The Council is charged with the responsibility for regulating and controlling Pharmacy Education, training and practice in all aspects and ramifications. There are about 21,892 registered pharmacists in Nigeria but data suggests that only $12,807(58.5 \%)$ are in active professional practice as indicated by the number of licensed pharmacists. ${ }^{104}$

The function of the Council includes determining what standards of knowledge and skills to be attained by persons seeking to become pharmacists in Nigeria. Establish and maintain a register of pharmacists and secure the publication from time to time of the list of those names as entered in the register; issue pharmacists oath and code of ethics; appoint pharmaceutical inspectors to ensure the enforcement of the provisions of the law by inspection and monitoring of premises where pharmaceutical endeavors take place; and maintain a register of pharmacy technicians. ${ }^{105}$ The Act provides that a person who is to be fully registered as a pharmacists must be of good character and a fit and proper person; has attended a course of training approved by the Council under section 15 of the Act and was conducted in an approved institution and holds a qualification approved by the Council and pays the prescribed fees. ${ }^{106}$

\section{f. Medical Laboratory Science Council}

The Medical Laboratory Council of Nigeria (MLCN) is a Federal Government Regulatory Agency. ${ }^{107}$ It functions as parastatals of the Federal Ministry of Health. The Council has the responsibilities of regulating Medical Laboratory Services through registration and licensing of medical laboratories as well as practitioners, mandatory inspection, monitoring and evaluation as well as certification of Laboratory test kits and reagents. ${ }^{108}$

The Act further empowers the Council to regulate the training of Medical Laboratory Scientists, Technicians and Assistants. ${ }^{109}$ The mandate of the Council by law is to regulate the standards from time to time to meet the changing health needs of the society. ${ }^{110}$ As earlier noted in this paper, there are about 14 professional regulatory bodies charged with the

103 Act 91 of 1992 now Cap P17 LFN 2004, https//www.pcn.gov.ng/ (Last accessed 4 October 2020).

104 Ekpenyong, A. et. al., "An Analysis of Pharmacy Workforce Capacity in Nigeria" Journal of Pharmaceutical Policy and Practice, Vol. 11:20, (2018), P7.

105 Section 1(1) (9) - (d) Pharmacist Council of Nigeria Act.

106 Section 11(1) (a) - (i) - (vi) Pharmacists Council of Nigeria Act.

107 Established by Act 11 of 2005.

108 Medical Laboratory Science Council of Nigeria, http://www.medicalwordnigeria.com/ (Last accessed 4 October 2020).

109 Ibid.

110 Ibid. 
responsibility of ensuring the education, training and setting of standards in the various areas of healthcare in Nigeria. But this paper has tried to present a general overview by focusing on the National Health Act, The Medical and Dental Practitioners Act, the National Health Policy and Nursing and Midwifery Council of Nigeria, the Pharmacy Council and the Medical Laboratory Council of Nigeria.

\section{Sanitary Standards in the Healthcare System}

From all the laws evaluated in respect to the regulation of the provision of facilities and equipment in the hospitals none specifically made mention of sanitary facilities but it may be presumed that this falls under the general heading of medical equipment and facilities. Adejumo et al., notes that appropriate and adequate sanitation, good hygiene and safe water supply are the basics for good health, social, economic and educational development. ${ }^{111}$ Esrey noted that if the morbidity rates and severity of various diseases will be reduced and we see an improvement in the quality of life of a greater number of Nigerians, then there should be an improvement in these sanitation components of health. ${ }^{12}$ The World Health Organisation defined sanitation thus: 'sanitation refers to public health conditions related to clean drinking water and adequate treatment and disposal of human waste and sewage'. ${ }^{113}$

The human rights to water and sanitation was recognized by the United Nations (UN) General Assembly in 2010. ${ }^{114}$ Sanitation is a global priority and the subject of sustainable development goal 6. ${ }^{115}$ A review of the SDG progress by the United Nations in 2002 found that increasing donor commitments to the water sector will remain crucial to make progress towards goal $6 .{ }^{116}$ It is noted that safe drinking water and hygienic toilets protect people from diseases and enable societies to be more productive economically. To meet the SDG targets for sanitation by the year 2030, almost one-third of countries will need to accelerate progress to end open defecation. ${ }^{117}$ SDG 6 is closely linked with other sustainable develop-

111 Adejumo, M. et al., 'Water and Sanitary Condition of a Typical Faculty of Public Health Building in a Nigerian University', Science Journal of Public Health, Vol. 5; No. 2, (2017), Pp. 103 - 109 at 103 .

112 Esrey, S.A et al., 'Effect of Improved Water Supply and Sanitation on Ascariasis, Diarrhoea, Dracunculiasis, Hookworm infections, Schistosomiasis and Trachoma', Bulletin of World Health Organisation, Vol. 69, (1991), Pp. $609-621$.

113 WHO and UNICEF, Progress on Drinking Water, Sanitation and Hygiene: Update and SDG Baselines, (Geneva: 2017).

114 Ibid.

115 Sustainable Development Goal 6 (SDG 6 or global goal 6) is about clean water and sanitation for all: it is one of the sustainable development goals established by the UN General Assembly in 2015: The official wording is: Ensure Sustainable Management of Water and Sanitation for All. The goal has eight target to be achieved by at least 2030 .

116 United Nations Economic and Social Council, 'Progress Towards the Sustainable Development Goals of the Secretary General (2020).

117 These countries include: Brazil, China, Ethiopia, India, Indonesia, Nigeria and Pakistan. 
ment goals. For instance progress in SDG 6 will improve health ${ }^{118}$ and improve school attendance which will both contribute to poverty alleviation. In April 2020, the UN Secretary General Antonio Guterres said: 'Today, sustainable development goal 6 is badly off track' and it is "hindering progress on the 2030 Agenda, the realization of human rights and the achievement of peace and security around the world". ${ }^{119}$

Proper sanitation is a sine qua non to good health. The WHO posits that Health is a state of physical, mental and social well-being in which disease and infirmity are absent. ${ }^{120}$ In 2017 , it was observed that 2.2 billion people lacked safely managed drinking water and 4.2 billion people lacked managed sanitation. ${ }^{121}$ Three billion people worldwide lack basic hand washing facilities at home and two in five health care facilities worldwide have no soap and water, or alcohol based hand rub as at 2016. ${ }^{122}$ The Covid-19 pandemic has made this goal increasingly important. ${ }^{123}$ This pandemic could affect the ability of water utilities to meet this goal by increasing losses on revenues that would otherwise be used to make investments. ${ }^{124}$ Frequent and proper hand washing is the most basic front line defense against Covid-19, yet a quarter of the World's population lacks access to a reliable water supply. ${ }^{125}$ The pandemic has heightened awareness of both the extent and consequences of this access gap and this could slow down progress in meeting SDG 6. ${ }^{126}$

Despite hand washing with soap being one of the critical first lines of defense against the spread of highly contagious and deadly corona virus disease, $95 \%$ of all health care centers in Nigeria are at risk of becoming epicenters of the disease due to lack of access to combined water, sanitation and hygiene services, putting the lives of doctors, nurses, midwives and patients at risk. ${ }^{127}$ Worse still, about 150 million people (79\%) in Nigeria do not have somewhere to wash their hands with soap and water. Prior to Covid-19 pandemic, healthcare centers in Nigeria have existed with insufficient sanitary facilities. It is noted that 'most primary health centers in Nigeria lack good washing facilities. At Lugbe PHC, there is no washing sink in the labour room, so water has to be fetched from the tap outside

118 SDG 3 is for Health.

119 Goal 6. Department of Economics and Social Affairs, https://www.un.org/. (Last accessed 4 October 2020).

120 World Health Organization, Constitution of the World Health Organisation, Basic Document, Forty-fifth edition, supplement, October, 2006.

121 Goal 6.

122 Ibid.

123 United Nations Economics and Social Council (n 116).

124 IFC, 'The impact of Covid-19 on Water and Sanitation', https://www.ife.org/. (Last accessed 4 October 2020). International Finance Corporation (IFC) is a World Bank Group.

125 Ibid.

126 Ibid.

127 Water Aid, 'The Scandal of $95 \%$ of Healthcare Centers in Nigerian and 150 million Nigerians without Access to Water and Hygiene Facilities in the Face of Covid-19 Pandemic', May 2020, https://www.wateraid.org/ (Last accessed 4 October 2020). 
and brought to the patient. A health worker who wants to wash her hands will have to fetch a bucket. It is not possible for health workers at the facility to do their jobs as midwives without access to water, sanitation and hand washing stations. ${ }^{128}$

The Well-being Foundation Africa and their partners are committed to improving Water, Sanitation and Hygiene (WASH) in healthcare facilities, households, school and communities across Nigeria. ${ }^{129}$ Nigeria boasts of having the fastest growing economy in the African continent, yet one-third of its population do not have access to clean water, twothirds do not have access to basic private toilets and one in the three health centers or facilities in Nigeria do not have access to water. ${ }^{130}$

The Water-Aid raises a poser thus:

Imagine a doctor's surgery with gallons of water lined up in jerry cans, purchased because the taps are dry. Lab technicians washing out excrement samples in hand basins without running water. As many as 40 patients a day with only one fetid, backedup toilet in which to relieve themselves. ${ }^{131}$

The absence of proper sanitation in Nigeria has led to the overuse of antibiotics in healthcare centers to treat and protect against infections and this is a major cause of the growing threat of anti-microbial resistance. ${ }^{132}$ Water Aid, in celebrating universal health coverage revealed that there is a silent emergency of erratic to non-existent water supply, broken toilets and poor hygiene, which puts the health of patients, staff and surrounding communities at risk. ${ }^{133}$

In Zuba, Primary Health Centre, Abuja, healthcare staff reports that there is no water supply; even the water they buy is not safe to drink. ${ }^{134}$ This situation is not peculiar to staff and patients at Zuba Primary Health Centre Abuja. Water Aid Nigeria study of 242 health facilities across six states - Bauchi, Benue, Enugu, Ekiti, Jigawa and Plateau revealed that $21 \%$ has access to a motorized water borehole. Only $20 \%$ of healthcare centers had hand washing facilities alongside their toilets. ${ }^{135}$

128 Momoh, Rita is a wellbeing foundation Africa midwife.

129 Wellbeing Africa, 'WASH-Water, Sanitation and Hygiene' https://www.wbafrica.org/content/was h. (Last accessed 4 October, 2020).

130 Martin, L, 'Caring for Patients without Clean Water and Sanitation in Nigeria', https://www.wate raid.org/healthprofessionals/ (Last accessed 27 September 2020). See also https://www.reliefweb. $\mathrm{int} /$ report/nigeria/caring-patients-without-clean-water-and-sanitation-nigeria. (Last accessed 27 September 2020).

131 Ibid.

132 Ibid.

133 Ibid.

134 Ibid.

135 Water Aid (n 127). 
Yael Valleman ${ }^{136}$ observed that:

All too often, health conditions in many low and middle income countries are characterized by unreliable or non-existent water supply, inadequate sanitation and unsafe medical waste disposal. The situation leaves healthcare professional unable to properly care for patients and leave doctors, midwives, nurses, cleaners and patients alike at serious risk of infections and illness. Good health, dignified and clean healthcare, and effectively combating the rise of antimicrobial resistance requires clean water, good sanitation and good hygiene practice in home, schools and in hospitals and healthcare centers around the world. Across the developing world, $38 \%$ of healthcare facilities do not have access to water.

The above situation from Water Aid cannot be over emphasized. Healthcare facilities in Nigeria lack proper sanitation and water and cannot meet the SDG 3 if the trend continues. Another trend in Nigeria's healthcare centers and facilities is the uncoordinated approach to waste management. Healthcare facilities are expected to implement a sustainable process that properly separates regulated from unregulated medical wastes at all times but unfortunately only a few medical facilities can boast of an effective systems that manages both solid and liquid wastes. ${ }^{137}$

We need to reiterate that lack of sanitation in Nigeria directly impacts healthcare services. For instance, $29 \%$ of hospitals and clinics in Nigeria do not have access to clean water or safe toilets. Patients' immune systems are already weak and poor sanitation significantly increase the risk of infection and complication. ${ }^{138}$

Improving sanitation in Nigeria is crucial to making progress on health and economic development. To achieve better health for everyone, everywhere, we need the Universal Health Coverage. This indicates that Nigeria has to look at what underpins good health: the environment, the air we breathe, food we eat; and whether we have clean safe water to drink, decent toilets, clean and hygienic surroundings.

\section{Recommendations and Conclusion}

This paper examined the legal framework to ensure sufficient medical equipment, training of medical staff and ensuring sanitary standards in the national healthcare system of Nigeria. To achieve the goal of this paper various laws addressing the specific areas under study were examined. It was discovered that although there are existing legal frameworks in the

136 Valleman, $Y$, is a Water Aid senior policy analysis on health and hygiene.

137 'Six Biggest Issues with Healthcare in Nigeria' (n 84) p3; Effective medical waste management process will encompass a regular collection, handling, storage, transportation of processing of waste. This is addition to creating conducive environment, can significantly reduce the transmission and spread of microorganisms, infection in healthcare facilities.

138 Cullen, M. '10 Facts about Sanitation in Nigeria', https://www.borenproject.org/facts-about-sanit ation-in-Nigeria/ (Last accessed 28 September 2020). 
nation, the implementation of these laws have been a problem. The Constitution which is the grund-norm provides for adequate medical facilities for the citizens but this provision cannot be enforced in any court as the provision falls under the social objective - directive principles of state policy. It is recommended that this provision should be made an enforceable right in Nigeria.

The paper also observed that the African Charter on Human and Peoples Rights that has been domesticated has no legal value in the domestic courts thereby making it difficult for citizens to make demands relating to health on government. The time has come to change this stance and allow the domestic courts to adjudicate on this regional legislation. Nigeria should amend her laws to bring it in line with the international obligations she signed up to. The National Health Act which is the principal legislation in the field of health has very laudable provision but its implementation depends heavily on the provision of fund from the central government through annual appropriation. Unfortunately, the health sector has never received sufficient funds. The $1 \%$ from the consolidated revenue has never been met. Health budget in Nigeria is lower than the budget for education and security even in the face of covid-19 pandemic. It is recommended that the government should increase allocation to the health sector and strive to achieve the $15 \%$ of annual budget allocation agreed to by the African Union and contained in the Abuja Declaration.

Provision of sufficient medical equipment and training of Human Resources for Health (HRH) will not be achieved without adequate funding. The National Health Policy has been drawn up but the goals and initiative contained therein cannot be actualized unless the $1 \%$ dedicated sum from the consolidated revenue is made available to the Federal Ministry of Health. The paper further observed that there are plethora of institutions dedicated to training of health personnel in the country. Some of these institutions have lost their accreditation due to lack of equipment and manpower. Incessant industrial actions by university teachers and health workers in Nigeria contributes immensely to the dearth in expertise in the health sector. Public Universities in Nigeria were on strike for nine months (March- December 2020) and are due to resume academic activities in January 2021 but the second wave of the corona virus pandemic has made the future quite bleak for tertiary institutions in Nigeria. Medical students and others have lost a session and this is not the best.

The federal and state governments are called upon to take stock of these institutions and make available the needed resources for them to purchase the required facilities and engage the necessary manpower. It was also observed that there are 14 regulatory institutions charged with the responsibilities of training healthcare personnel in the country. These institutions have their challenges in the areas of weak structures and poor institutional capacities to carry out their functions. There is a need to strengthen these institutions and reposition them for greater efficiency if Nigeria must achieve universal coverage.

Closely linked with training of medical personnel is the misdistribution of these personnel. Some health facilities especially at the primary health care level in the villages lack personnel and this had led to the massive influx in the secondary and tertiary facilities thereby stretching the few equipment that exists there. Nigeria, despite the number of medical 
and health personnel that qualify every year is still in dire need of staff. In the public sector, most health professionals would rather travel out of the country in search of greener pasture or run to a private clinic. This because welfare packages for medical and health personnel is not encouraging. The government must consider and treat the issue of health as essential service and improve the welfare and security of health workers.

On sanitation, the paper observed that although sanitation happens to be the Sustainable Development Goal 6 (SDG 6), Nigerian health sector is still behind in the attainment of this goal. Hospitals were noted not to have water and sufficient toilet facilities. There is also the problem of unsanitary mode of waste disposal in the hospitals. It is recommended that motorized boreholes and toilet facilities should be provided for the hospitals and health centers as this will help to cut the spread of diseases that are waterborne. It will also help to stop open defecation in the hospitals and its environs. Health is wealth and a healthy nation is a wealthy nation. With sufficient medical equipment; trained and evenly distributed health personnel and proper sanitation, Nigeria would achieve universal coverage for health and medical tourism would be a thing of the past. On 5 November 2020 during the budget defense by the Permanent Secretary to the State House, the Senate noted that the President and government officials will no longer be allowed to travel abroad for medical care as that would compel the government to fix the State House Clinic as the budget of 1.3 billion Naira was approved for the clinic.

\section{Bibliography}

Adejumo, M. et al., 'Water and Sanitary Condition of a Typical Faculty of Public Health Building in a Nigerian University', Science Journal of Public Health, Vol. 5, No. 2, (2017) Pp 103 - 109 at 103.

Adepoju, P., 'Nigeria's nationwide Health Workers Strike Bites Harder at UCH Ibadan' https://www.he althnews.ng/nigeria-nationwide-health-workers-strike-Ibadan,https://www.healthnews.ng/Nigerianationwide-health-workers-stike-bites-harder-at-uch-ibadan/ (Last accessed 27 September 2020).

Adie Vanessa Offiong. 'Nigeria: A Pandemic and a Weak Health System, https://www.gga.org/nigeria-a -pandemic-and-a-weak-health-system/ (Last accessed 27 September, 2020). See also 5 Challenges Facing Healthcare Workers in Nigeria as they Tackle COVID-19, https://www.globalcitizen.org/en /content/challenges-facing-health-care-workers-an-Nigeri-covid/ (Last accessed 27 September 2020).

African Charter on Human and Peoples' Rights (Ratification and Enforcement) Act, Cap A9 Laws of Federation of Nigeria (2004).

Akpoghome, T. U. and Nwano, T. C., 'State Funding of Public Institutions in Nigeria: Control Mechanisms and Legal Challenges', KAS African Law Study Library, Vol. 4, No. 6, (2019), Pp. 541-562 at 557 .

Aregbeshola, B.S and Khan, S M., 'Predictors of Enrolment in the National Health Insurance Scheme among Women of Reproductive Age in Nigeria', International Journal of Health Policy and Management, Vol. 7, No. 1, (2018), Pp 1015 - 1023, https://www.nobi.nlm.nih.gov/articles/ (Last accessed 29 September 2020). 
Aworinde, T., 'COVID - 19 Exposes Nigeria's Wobbling Healthcare System' https://www healthwise.punching.com/covid-19-exposes-nigeria-nobbling-healthcaresystem/ (Last accessed 27 September 2020).

Constitution of the Federal Republic of Nigeria 1999 as amended 2011.

Cullen, $M$. ' 10 Facts about Sanitation in Nigeria', https://www.borenproject.org/facts-about-sanitationin-Nigeria/ (Last accessed 28 September 2020).

Ekpenyong, A. et al., "An Analysis of Pharmacy Workforce Capacity in Nigeria" Journal of Pharmaceutical Policy and Practice, Vol. 11:20, (2018), Pp. 1-9

Esrey, S.A et al., 'Effect of Improved Water Supply and Sanitation on Ascariasis, Diarrhoea, Dracunculiasis, Hookworm infections, Schistosomiasis and Trachoma', Bulletin of World Health Organisation (1991), Vol. 69, Pp. $609-621$.

Federal Ministry of Health National Health Policy 2017 (Abuja: 2017)

Goal 6. Department of Economics and Social Affairs, https://www.un.org/. (Last accessed 4 October 2020).

IFC, 'The impact of Covid-19 on Water and Sanitation', https://www.ife.org/. (Last accessed 4 October 2020). International Finance Corporation (IFC) is a World Bank Group.

Igomu, T., 'I Didn't Know that Nigeria's Health Sector was this Bad- Boss Mustapha', April 102020 , https://www.healthwise.punchng.com. (Last accessed 28 September 2020).

International Covenant for Economic and Social Rights (ICESCR), 1966

Martin, $L$, 'Caring for Patients without Clean Water and Sanitation in Nigeria', https://www.wateraid.o rg/healthprofessionals/ (Last accessed 27 September 2020). See also https://www.reliefweb.int/rep ort/nigeria/caring-patients-without-clean-water-and-sanitation-nigeria. (Last accessed 27 September 2020).

Medic West Africa, “2019 Health Care Market Insights: Nigeria”, http://www.medicwestafrica.com/co ntent/dam/informa/medic-west-afeica/englis/2019/healthcareinsight.pdf/ (Last accessed 27 September 2020).

Medical and Dental Practitioners Act, Cap M8, LFN 2004.

Medical Laboratory Science Council of Nigeria, Established by Act 11 of 2005 http://www.medicalwor dnigeria.com/ (Last accessed 4 October 2020).

Mwai, P. and Cules, C., "Corona Virus: How vulnerable are Health workers in Nigeria", http://www.bb c.com/news.world-a/. See also Corona Virus Kills Brilliant Doctors in Nigeria”, http://www.bbc.co $\mathrm{m} /$. (Last accessed 29 September 2020).

National Health Act 2014.

National Health Facility List, 2011, Federal Ministry of Health.

National Health Policy 2017, Objective of the Health Policy for Human Resources for Health.

National Heath Policy Goal on infrastructure 2017.

Nursing and Midwifery (Registration etc.) Act Cap N143, Laws of Federation of Nigeria, 2004, https:// www.nncn.gov.ng/ (Last accessed 3 October 2020).

Nwariaku, F., 'Performance of Medical Graduates within and Outside', Nigeria Medical Journal, Vol. 51, No. 2 (2010), p1, https://www.ajol/info/index.php/nmj/articles/ (Last accessed 2 October 2020). 
Obaseki, D. E., "Staff Risks Stratification in Preparation for Covid - 19 in a Tertiary Healthcare Facility in Nigeria", Pan African Medical Journal, Vol. 35, No. 2, (2020), https://wwwpanafrican-med-j ournal.com/content/series/3/2/124/full/ (Last accessed 3 October 2020).

Obaseki, D.E. "Nigeria: 800 Health Workers Infected with Covid - 19, http://www.ac.com.tr/africa/nig eria-800-health-workers-infected-with-covid-19/, See also https://www.panAfrican-med-journal.c om. (Last accessed 29 September 2020).

Olufemi Joshua, 'Nigeria budgets N2,000 for the Healthcare of each citizen in $2020 \mathrm{https}$ ://ww.premui mtimesng.com/health/health-feature/361373-nigeria-budgets-n2000-for -the-healthcare-of-each-cit izen-in-202.html/ (accessed 27 September 2020).

Pharmacist Council of Nigeria Act 91 of 1992 now Cap P17 LFN 2004, https//www.pcn.gov.ng/ (Last accessed 4 October 2020).

Situation Analysis of the Federal Ministry of Health, p 18.

Sustainable Development Goal 6 (SDG 6 or global goal 6) is about clean water and sanitation for all: it is one of the sustainable development goals established by the UN General Assembly in 2015: The official wording is: 'Ensure Sustainable Management of Water and Sanitation for All'. The goal has eight target to be achieved by at least 2030 .

The Six Biggest Issues with Healthcare Services in Nigeria and how FM can Help', https://www.amfac ilities.com/wp-content/uploads/2016/10/HEALTHCARE-blog-banner.jpg/. (Last accessed 1 October 2020).

Umeha, Chioma, 'Nigeria's grossly Inadequate 2017 Health Budget https://www.thisdaylive.com/index .php/2017/02/09/nigerias-grossly-inadequate-2017-health.budget/ (Last accessed 27 September 2020).

United Nations Economic and Social Council, 'Progress Towards the Sustainable Development Goals of the Secretary General (2020).

Valleman, $Y$, is a Water Aid senior policy analysis on health and hygiene.

Water Aid, 'The Scandal of $95 \%$ of Healthcare Centers in Nigerian and 150 million Nigerians without Access to Water and Hygiene Facilities in the Face of Covid-19 Pandemic', May 2020, https://ww w.wateraid.org/ (Last accessed 4 October 2020).

Wellbeing Africa, 'WASH-Water, Sanitation and Hygiene' https://www.wbafrica.org/content/wash. (Last accessed 4 October, 2020).

WHO and UNICEF, Progress on Drinking Water, Sanitation and Hygiene: Update and SDG Baselines, (Geneva: World Health Organisation WHO and the United Nations Children Fund (UNICEF) 2017).

World Health Organization, Constitution of the World Health Organisation, Basic Document, Fortyfifth edition, supplement, October, 2006 